\title{
Quality Analysis of Mango Fruit Waste for Utilization in Food Products
}

\author{
G. Gurumeenakshi*, N. Varadharaju and R. Rajeswari \\ Centre for Post Harvest Technology, Agricultural Engineering College \& Research Institute \\ Tamil Nadu Agricultural University, Coimbatore, India \\ *Corresponding author
}

\section{A B S T R A C T}

Keywords

Mango peel, Pomace, Chemical preservatives, Sensory evaluation and Microbial examination

Article Info

Accepted:

04 February 2019

Available Online:

10 March 2019
Mango (Mangifera indica Linn.) is one of the most important tropical fruits in the world. About $20 \%$ of the fruits are processed for products such as puree, nectar, leather, pickles and canned slices, which have worldwide popularity. During the processing of mango, several million tons of wastes are produced annually from factories in which peel and pomace each contributes about $15-20 \%$ of the mango fruit. As peel and pomace are rich in phytochemicals, fibre and vitamin $\mathrm{C}$ are not currently utilized for any commercial purpose and it is discarded as a waste and becoming a source of pollution. There is a need to develop cheap and commonly available technology for extending the shelf life of these produce. Chemical preservatives are used for providing the preservation effect to the stored mango peel and pomace as it controls the growth of microorganisms and also maintain the keeping quality of the stored products.

\section{Introduction}

Mango (Mangifera indica L.), belongs to the family Anacardiaceae, is one of the most cultivated fruit in the world. Being a seasonal fruit with limited shelf-life, the fruit quality drops down rapidly once it is fully ripen. About $20 \%$ of the fruits are processed for products such as puree, nectar, leather, pickles and canned slices, which have worldwide popularity (Ashoush and Gadallah, 2011). The mango pulp industry in Krishnagiri and Dharmapuri district of Tamil Nadu are the second largest exporter of pulp in the country, after Chittoor in Andhra Pradesh. There are about 75 industries with a turn over Rs. 10 crore in these two areas. The major activities of these industries are canning of mango pulp for export to UAE, European countries, Singapore and Malaysia. The peak season of the factories are from March - August, where in the units functions in two shifts.

During the processing of mango, several million tons of wastes are produced annually from factories in which peel is a major byproduct. Peel and pomace each contributes about $15-20 \%$ of the fruit (CFTRI, 1985). As 
peel and pomace that are rich in fibre are not currently utilized for any commercial purpose and it is discarded as a waste and becoming a source of pollution. Peel has been found to be a good source of phytochemicals such as polyphenols, carotenoids, vitamin E, dietary fibre and vitamin $\mathrm{C}$ and it also exhibited good antioxidant properties (Ashoush and Gadallah, 2011). Studies have been conducted on the utilization of mango kernels as a source of fat (Arogba, 2002), natural antioxidants (Kaur, 2004), starch (Moharram and Moustafa, 1982), flour (Puravankara et al., 2000) and feed (Ravindran and Sivakanesan, 1996) but studies on the mango peels and pomace are found to be scarce (Berardini et al., 2005).

According to Ojokoh (2007), mango peel fibre is a good source of dietary fibre and its chemical composition may be compared to citrus fibre. Mango peels are found to possess higher values of anticancer properties because of polyphenolic extracts (Noratto, 2010) and glucose retardation (Reyers and Vega, 1988). Chemical in peels of certain mango cultivars have also been shown to prevent the formation of fat cells through disrupting adipogenesis (Taing et al., 2012) which is the key in the development of obesity (Min et al., 2013).

After processing the mango waste storage for preserving quality is potentially problematic, and therefore they are forced to discard it. There is a need to develop cheap and commonly available technology for extending the shelf life of these produce. So the work studied the different methods and treatments to extend the shelf life of mango peel and pomace as it contains high moisture.

\section{Materials and Methods}

\section{Variety}

Several varieties of mango are grown in India, which include Banganapalli, Suvarnarekha,
Neelum, Totapuri, Kesar, Alphonso, Rajapuri, Jamadar, Chausa, Dashehari, Fazli, Gulabkhas, KishenBhog, Himsagar, Zardalu and Langra. For this study Alphonso and Totapuri has been selected.

\section{Collection of sample}

After pulp extraction from fruit (mesocarp part), peel, pomace and kernel are discarded as waste and becoming a source of pollution. The samples mainly ripe mango peels and fibrous pomace at laboratory scale were collected and used for the study.

\section{Preparation of sample}

The collected samples (mango peel) were washed with running water to remove dirt and dust. The peel were spread in a tray to remove the moisture content and treated with the preservatives and stored in amber bottle for shelf life study. The pomace were also collected and treated accordingly and stored in amber bottle (Table 1).

\section{Proximate analysis of the mango peel and pomace}

Mango peel contains significant amount of moisture and are rich in pectin, cellulose, hemicelluloses, lipids, proteins, polyphenols and carotenoids. In general, the level of reducing sugars, non - reducing sugars, protein and cellulose varies depending on cultivar. The collected peel and pomace were analyzed for its qualities using standard AOAC methods both at 0 and 90 days.

\section{Microbiological examination of the mango peel and pomace}

The microbial loads of the samples were enumerated by the method described by Istavankiss (1984). Ten gram of the sample was taken in $90 \mathrm{ml}$ sterile water blank and 
thoroughly mixed in a rotary shaker for 10 minutes. From the solution, a series of $10^{-6}$ dilution were obtained using serial dilution techniques and was used for the estimation of total plate count. From the $10^{-6}$ dilution, $1.0 \mathrm{ml}$ of the sample was poured into a petri plate and rotated clockwise and anticlockwise for the uniform spreading of the sample. Nutrient agar medium was then added and allowed to solidify. After solidification the plates were incubated at room temperature $\left(28 \pm 2^{\circ} \mathrm{C}\right)$ for 24 to 28 hours and the colonies were counted.

\section{Sensory quality of the mango peel and pomace}

The quality parameters like color, flavor, texture, taste and overall acceptability of the fresh and stored samples were organoleptically evaluated using 9 - point hedonic scale by a panel of 15 semi trained judges.

\section{Results and Discussion}

\section{Proportions of mango peel, pulp and} pomace

The different components obtained during the mango processing are presented in table 2 .

After pulp extraction from fruit, the percentage of peel and pomace in both the variety accounted for $15-16 \%$ and the pulp was ranging from $68-69 \%$. The pomace was more in alphonsa compared to Totapuri, which might be due to a varietal difference.

After pulp extraction from fruit, the peel and pomace are discarded as waste and they account for $35-55 \%$ of the fruit. The percentage of different components obtained during mango pulp extraction are mango pulp $(45-65 \%)$, peel $(15-20 \%)$, pulpier waste $(15-20 \%)$ and stone $(10-20 \%)$ depending on the variety (Pradeep et al., 2014).

\section{Shelf life study of mango peel and pomace}

The mango waste samples were divided into 2 sub lots namely: Peel and pomace and were given different treatments and compared with the control sample and it is displayed in table 3.

The treated samples were kept in refrigeration for 90 days by storing in amber colored pet jars. Visible deterioration of the control was observed as rotting of fruits in all the treated samples within few days of storage and therefore it is been discarded. The samples that were treated with citric acid and citric acid + KMS were able to keep up the keeping quality for 90 days and these samples were further subjected to the quality analysis.

No preservative on its own is absolutely efficient against the entire microorganisms. For the longer time storage of preservation of mango peel, the frequently used preservatives are potassium metabisulphite (KMS) and citric acid because of their superior antimicrobial action (Madau et al., 2013)

\section{Proximate analysis of the peel and pomace}

The Typical composition of the peel and pomace is given in table 4 .

In recent years, this fruit processing waste has received much attention as a potential source of value products and it is inferred from the table that the fresh mango peel contain the highest $\beta$ carotene content and hence it can be used as a substrate for the solvent extraction of $\beta$ carotene. The moisture content ranged from 70 to 85 per cent, TSS $20-27^{0}$ bx, acidity 4.0 to 4.4 per cent, reducing sugars 7 to $12 \mathrm{~g}$, non reducing sugars 3 to $6 \mathrm{~g}$ per $100 \mathrm{~g}$ respectively. The $\beta$ carotene content of the fresh mango peel ranged between 274 - 286 $\mathrm{mg}$, while that of the pomace ranged between 214-233 mg per $100 \mathrm{~g}$. 
During the storage period of 90 days the peel and pomace has found to be in loss of moisture to a considerable level and only minimal reduction of $\beta$ carotene value was identified and this ensured that the peel can be stored and utilized for the extraction of $\beta$ carotene from the samples.

Recently, mango peels have attracted considerable attention in the scientific community due to their high content of valuable compounds, such as phytochemicals, polyphenols, carotenoids, enzymes, vitamin E and vitamin $\mathrm{C}$, which have predominant functional and antioxidant properties (Ajila $e t$ al., 2007).

Moreover Sogi et al., (2013) reported mango peels as a rich source of dietary fibre, cellulose, hemicellulose, lipids, protein, enzymes and pectin. These valuable compounds are also beneficial for human health.

Table.1 Treatments for extension of shelf life of mango wastes

\begin{tabular}{|l|l|c|c|c|}
\hline \multirow{2}{*}{ Variety } & Proportion & \multicolumn{3}{|c|}{ Treatment (\%) } \\
\cline { 3 - 5 } & & $\mathrm{T}_{0}$ & $\mathrm{~T}_{1}$ & $\mathrm{~T}_{2}$ \\
\hline \multirow{2}{*}{ Alphonso } & Mango peel & - & 1 & 1 \\
\cline { 2 - 5 } & Pomace & - & 1 & 1 \\
\hline \multirow{2}{*}{ Totapuri } & Mango peel & - & 1 & 1 \\
\cline { 2 - 5 } & Pomace & - & 1 & 1 \\
\hline
\end{tabular}

Table.2 Proportions of Mango Peel, Pulp and Pomace

\begin{tabular}{|c|c|c|c|c|}
\hline S. No & Variety & Proportion & Weight (g) & $\%$ \\
\hline \multirow[t]{5}{*}{1.} & \multirow[t]{5}{*}{ Totapuri } & Mango & 165.4 & 100 \\
\hline & & Peel & 28.118 & 17 \\
\hline & & Pomace & 24.81 & 15 \\
\hline & & pulp & 112.472 & 68 \\
\hline & & Overall & 165.4 & 100 \\
\hline \multirow[t]{5}{*}{2.} & \multirow[t]{5}{*}{ Alphonso } & Mango & 187.7 & 100 \\
\hline & & Peel & 28.155 & 15 \\
\hline & & Pomace & 30.032 & 16 \\
\hline & & pulp & 129.513 & 69 \\
\hline & & Overall & 187.7 & 100 \\
\hline
\end{tabular}

Table.3 Shelf life study of mango peel and pomace

\begin{tabular}{|c|c|c|c|}
\hline Proportion & Treatment & \multicolumn{2}{|c|}{ Storage days (90 days) } \\
\cline { 3 - 4 } & & Alphonso & Totapuri \\
\hline Pulverized & $\mathrm{T}_{0}$ & 2 & 2 \\
\hline $\begin{array}{c}\text { Peel \& } \\
\text { Pomace }\end{array}$ & $\mathrm{T}_{1}$ & 90 & 90 \\
\cline { 2 - 4 } & $\mathrm{T}_{2}$ & 90 & 90 \\
\hline
\end{tabular}


Table.4 Proximate analysis of mango peel and pomace per 100g

\begin{tabular}{|c|l|c|c|c|c|c|c|c|c|}
\hline \multirow{2}{*}{$\begin{array}{c}\text { S. } \\
\text { No }\end{array}$} & \multirow{2}{*}{ Component } & \multicolumn{3}{|c|}{ Initial (0 days) } & \multicolumn{4}{c|}{ Final (90 days) } \\
\cline { 3 - 10 } & & \multicolumn{2}{|c|}{ Alphonso } & Totapuri & \multicolumn{2}{|c|}{ Alphonso } & Totapuri \\
\cline { 3 - 10 } & & $\mathbf{P}_{\mathbf{1}}$ & $\mathbf{P}_{\mathbf{2}}$ & $\mathbf{P}_{\mathbf{1}}$ & $\mathbf{P}_{\mathbf{2}}$ & $\mathbf{P}_{\mathbf{1}}$ & $\mathbf{P}_{\mathbf{2}}$ & $\mathbf{P}_{\mathbf{1}}$ & $\mathbf{P}_{\mathbf{2}}$ \\
\hline $\mathbf{1 .}$ & Moisture $(\%)$ & 72 & 80 & 70 & 85 & 69 & 78 & 68 & 83 \\
\hline $\mathbf{2 .}$ & Total Soluble Solids $\left({ }^{\circ} \mathrm{B}\right)$ & 23 & 29 & 20 & 27 & 20 & 27 & 18 & 25 \\
\hline $\mathbf{3 .}$ & Acidity $(\mathrm{g})$ & 4.3 & 4.1 & 4.4 & 4.0 & 4.3 & 4.1 & 4.4 & 4.0 \\
\hline $\mathbf{4 .}$ & Reducing sugars $(\mathrm{g})$ & 8 & 10 & 7 & 12 & 7 & 9 & 5 & 10 \\
\hline $\mathbf{5 .}$ & Non reducing sugars $(\mathrm{g})$ & 4 & 5 & 3 & 6 & 3 & 4 & 2 & 4 \\
\hline $\mathbf{6 .}$ & $\beta$ carotene $(\mathrm{mg})$ & 274 & 214 & 286 & 233 & 270 & 211 & 283 & 230 \\
\hline $\mathbf{7 .}$ & Cellulose and lignin $(\mathrm{mg})$ & 26 & 28 & 24 & 29 & 26 & 28 & 24 & 29 \\
\hline
\end{tabular}

Table.5 Microbial quality of the peel and pomace

\begin{tabular}{|c|c|c|c|c|c|c|c|c|c|c|c|c|c|}
\hline \multirow[t]{3}{*}{ Proportion } & \multirow[t]{3}{*}{ Treatment } & \multicolumn{6}{|c|}{ Alphonsa } & \multicolumn{6}{|c|}{ Totapuri } \\
\hline & & \multicolumn{3}{|c|}{ Initial } & \multicolumn{3}{|c|}{ Final } & \multicolumn{3}{|c|}{ Initial } & \multicolumn{3}{|c|}{ final } \\
\hline & & TPC & Fungi & Yeast & TPC & Fungi & Yeast & TPC & Fungi & Yeast & TPC & Fungi & Yeast \\
\hline \multirow[t]{3}{*}{ Peel } & $\mathrm{T}_{0}$ & 1.0 & 0 & 0 & 3.3 & 1.33 & 0 & 1.0 & 0 & 0 & 2.3 & 1.3 & 0 \\
\hline & $\mathrm{T}_{1}$ & 1.0 & 0 & 0 & 3.0 & 2 & 0 & 1.0 & 0 & 0 & 2.0 & 1 & 0 \\
\hline & $\mathrm{T}_{2}$ & 1.0 & 0 & 0 & 1.0 & 0 & 0 & 1.0 & 0 & 0 & 1.0 & 0 & 0 \\
\hline \multirow[t]{3}{*}{ Pomace } & $\mathrm{T}_{0}$ & 1.0 & 0 & 0 & 4.6 & 2.3 & 0 & 1.0 & 0 & 0 & 3.6 & 1.3 & 0 \\
\hline & $\mathrm{T}_{1}$ & 1.0 & 0 & 0 & 2.6 & 1.6 & 0 & 1.0 & 0 & 0 & 2.0 & 1.0 & 0 \\
\hline & $T_{2}$ & 1.0 & 0 & 0 & 1.0 & 0 & 0 & 1.0 & 0 & 0 & 1.0 & 0 & 0 \\
\hline \multirow[t]{3}{*}{ Peel } & $\mathrm{T}_{0}$ & 1.0 & 0 & 0 & 3.6 & 2.3 & 0 & 1.0 & 0 & 0 & 2.6 & 1.3 & 0 \\
\hline & $T_{1}$ & 1.0 & 0 & 0 & 2.0 & 1.3 & 0 & 1.0 & 0 & 0 & 2.0 & 1.0 & 0 \\
\hline & $\mathrm{T}_{2}$ & 1.0 & 0 & 0 & 1.0 & 0 & 0 & 1.0 & 0 & 0 & 1.0 & 0 & 0 \\
\hline \multirow[t]{3}{*}{ Pomace } & $\mathrm{T}_{0}$ & 0 & 0 & 0 & 4.6 & 2.6 & 0 & 0 & 0 & 0 & 2.6 & 1.0 & 0 \\
\hline & $\mathrm{T}_{1}$ & 0 & 0 & 0 & 2.3 & 1.3 & 0 & 0 & 0 & 0 & 2.3 & 1.0 & 0 \\
\hline & $\mathrm{T}_{2}$ & 0 & 0 & 0 & 1.0 & 0 & 0 & 0 & 0 & 0 & 1.0 & 0 & 0 \\
\hline
\end{tabular}

Total plate count $-10^{6}$, Fungi $10^{3}$ Yeast $10^{2} \mathrm{cfu} / \mathrm{g}$

Table.6 Sensory quality of the fresh peel and pomace

\begin{tabular}{|c|c|c|c|c|c|c|}
\hline \multirow{3}{*}{ Variety } & \multirow{3}{*}{ Proportion } & \multicolumn{5}{|c|}{ Sensory Attributes } \\
\hline & & $\begin{array}{l}\text { Color and } \\
\text { Appearance }\end{array}$ & Flavor & Texture & Taste & $\begin{array}{c}\text { Overall } \\
\text { Acceptability }\end{array}$ \\
\hline & & \multicolumn{5}{|c|}{ Initial (0 days) } \\
\hline & Peel & 8.1 & 8.6 & 8.5 & 8.5 & 8.6 \\
\hline \multirow[t]{2}{*}{ Alphonso } & Pomace & 8.2 & 8.5 & 8.4 & 8.5 & 8.6 \\
\hline & Peel & 8.8 & 8.3 & 8.6 & 7.9 & 8.8 \\
\hline \multirow[t]{2}{*}{ Totapuri } & Pomace & 8.1 & 8.4 & 8.9 & 8.7 & 8.9 \\
\hline & \multicolumn{6}{|c|}{ Final (90 days) } \\
\hline \multirow[t]{2}{*}{ Alphonso } & Peel & 8.1 & 8.6 & 8.5 & 8.5 & 8.6 \\
\hline & Pomace & 8.2 & 8.5 & 8.4 & 8.5 & 8.6 \\
\hline \multirow[t]{2}{*}{ Totapuri } & Peel & 8.8 & 8.3 & 8.6 & 7.9 & 8.8 \\
\hline & Pomace & 8.1 & 8.4 & 8.9 & 8.7 & 8.9 \\
\hline
\end{tabular}


Plate.1 Experimental design for the extension of shelf life of the mango waste

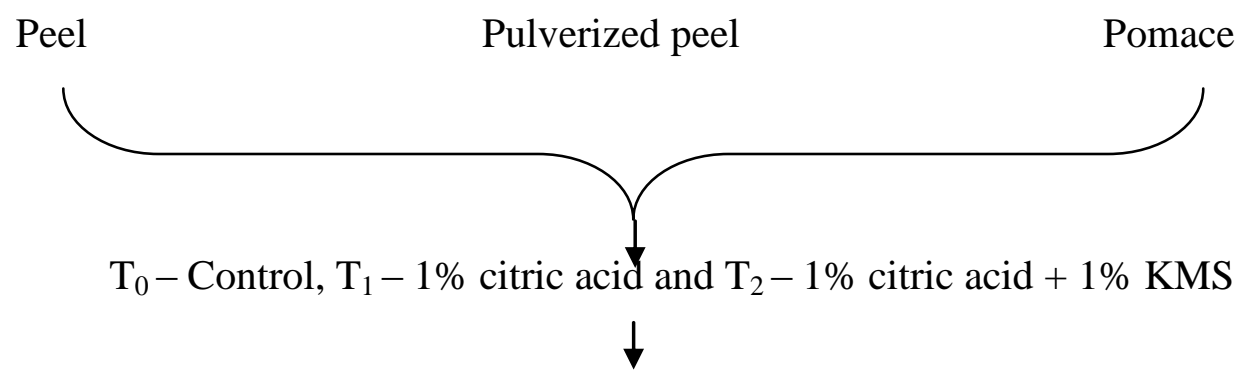

Sealed in polypropylene packs

Stored in amber colored pet jars

Stored in refrigeration temperature

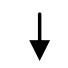

After 90 days of storage

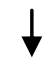

Quality analyis of the samples

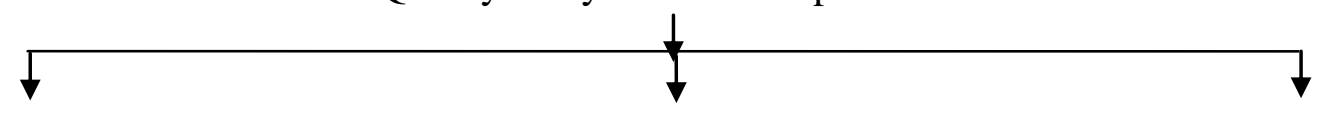

Proximate analysis $\quad$ Microbiological analysis $\quad$ Sensory analysis

Mango peels can be utilized for the production of valuable ingredients (i.e., dietary fibre and polyphenols) for various food applications, as has been reported by many researchers (Ajila et al., 2007; Ajila et al., 2010; Aziz et al., 2012).

\section{Microbiological examination of the peel and pomace}

The microbiological examination such as initial total plate count, yeast and mold count of the mango peel and pomace were done to ensure the safety of the product and the results are provided in the table 5 .
From the table 4 it could be inferred that, there was a minimum total plate count, while the fungi and yeast were below detectable level. This ensured that the product is safe for further utilization.

During storage period, it was found that there was a very slight increase in the Total plate count invariably in all the treatments. The growth of fungi and yeast was found in the all the treatments except $T_{2}$. Hence it could be inferred that storage of the peel and pomace with citric acid and KMS ensures the microbial safety of the product for a storage period of 90 days. 


\section{Sensory quality of the peel and pomace}

The sensory attributes namely color and appearance, flavor, texture, taste and overall acceptability was performed with the semi trained judges and the results are presented in table 6 .

The colour and appearance of the peel and pomace of both the varieties were highly acceptable as it is evident from the table. The results also indicated that there was no off flavor or a bitter taste in the peel and pomace. The texture was not very slimy in the peel and the pomace was not extremely coarse. Though both the variety has scored good overall acceptability level Totapuri variety ranks first due to its sweeter taste compared to Alphonso variety. The results established that the peel and pomace though considered as waste by the industry had highly acceptable sensory qualities.

The addition of preservatives during the storage period has prevented the browning of the peel and pomace and resembled as the fresh sample. Therefore the sample scored the similar value to that of the fresh sample.

In conclusion, it has been well documented that mango by-products, such as peels and pomace, contain high levels of various healthenhancing substances (i.e., phenolic compounds, carotenoids, vitamin $\mathrm{C}$ and dietary fibre). A broad study is needed not only for the recovery of valuable compounds, but also specific applications to ensure industrial exploitation and sustainability of the final product. And hence the present study has taken up and the added preservative has an impact on the quality of stored mango peel and pomace. At the end, it can be concluded that mango fruit by-products are potential sources of natural food ingredients. The recovery and utilization of valuable compounds from mango by-products is an important challenge for scientists. These valuable compounds in mango by-products could have a greater application in the food industry.

\section{References}

Ajila, C. M., Aalami, M., Leelavathi, K., and Prasada Rao, U. J. S. (2010). Mango peel powder: A potential source of antioxidant and dietary fiber in macaroni

Ajila, C.M., Bhat, S.G. and Rao, U.J.S.P. (2007) Valuable Components of Raw and Ripe Peels from Two Indian Mango Varieties. Food Chemistry, 102, 1006-1011. http://dx.doi.org/10.1016/j.foodchem.2 006.06 .036

Arogba, S. S. (2002). Quality characteristics of a model biscuit containing processed mango (Mangifera indica) kernel flour. International Journal of Food Properties, 5, 249- 260.

Ashoush, I. S., and Gadallah, M. G. E. (2011). Utilization of mango peels and seed kernels powders as sources of phytochemicals in biscuit. World Journal of Dairy \& Food Sciences, 6(1), 35-42.preparations. Innovative Food Science and Emerging Technologies, 11, 219-224.

Aziz, N. A. A., Wong, L. M., Bhat, R., and Cheng, L. H. (2012). Evaluation of processed green and ripe mango peel and pulp flours (Mangifera indica var Chokanan) in term of chemical composition, antioxidant compounds and functional properties. Journal of the Science of Food \& Agriculture, 92, 557-563.

Berardini, N., Knodler, M., Schieber, A. and Carle, R. 2005. Utilization of mango peels as a source of pectin and polyphenolics. Innov. Food Sci. Emerg. 6: 442-452. 
Central Food Technological Research Institute (CFTRI). 1985. Mango pulp concentration, Mysore, India. pp. 2539.

Kaur, M., Singh, N., Sandhu, K. S., and Guraya, H. S. (2004). Physicochemical, morphological, thermal and rheological properties of starches separated from kernels of some Indian mango cultivars $\begin{array}{lll}\text { (Mangifera indica } & \text { L.). } \quad \text { Food }\end{array}$ Chemistry, 85, 131-140.

Min SY, Yang H, Seo SG, Shin SH, Chung MY, Kim J, Lee SJ, Lee HJ, Lee KW (2013). Cocoa polyphenols suppress adipogenesis in vitro and obesity in vivo by targeting insulin receptor. Inter. J. Obesity. 37:584-592.

Moharram, Y. G., and Moustafa, A. M. (1982). Utilisation of mango seed kernel (Mangifera indica) as a source of oil. Food Chemistry, 8, 269- 276.

Mudau Fhatuwani Nixwell, Mabusela Johanna and Wonder Ngezimana, 2013. Effects of sulphur preservative on phytochemical and antioxidant capacity of peels of mango cultivars (Mangifera indica L.) produced in South Africa. African journal of biotechnology, Vol. 12(41), pp. 60076012, 9 October, 2013.

Noratto GD, Bertoldi MC, Krenek K, Talcott ST, Stringheta PC, Mertens-Talcott SU (2010). Anticarcinogenic effects of polyphenolics from mango (Mangifera indica) varieties. J. Agric. Food Chem. 58:4104-4112.

Ojokoh, A.O. 2007. Effect of fermentation on the chemical composition of mango
(Mangifera indica L.) peels. Afr. J. Biotechnol. 6: 1979-1981.

Pradeep Puligundla, Vijaya Sarathi Reddy Obulam, Sang Eun Oh and Chulkyoon Mok. 2014. Biotechnological Potentialities and Valorization of Mango Peel Waste: A Review. Sains Malaysiana 43(12)(2014): 1901-1906

Puravankara, D., Boghra, V., and Sharma, R. S. (2000). Effect of antioxidant principles isolated from mango (Mangifera indica L) seed kernels on oxidative stability of buffalo ghee (butter-fat). Journal of the Science of Food and Agriculture, 80, 522- 526

Ravindran, V., and Sivakanesan, R. (1996). The nutritive value of mango seed kernels for starting chicks. Journal of the Science of Food and Agriculture, $71,245-250$.

Reyers TT, Vega WF (1988). Factors involved in storage of many fruits: A new evaluation proceedings International Society Citriculture. pp 227-231.

Sogi, D. S., Siddiq, M., Greiby, I., and Dolan, K. D. (2013). Total phenolics, antioxidant activity, and functional properties of 'Tommy Atkins' mango peel and kernel as affected by drying methods. Food Chemistry, 141, 26492655.

Taing MW, Pierson JT, Hoang VL, Shaw PN, Dietzgen RG, Gidley MJ, RobertsThomson SJ, Monteith GR (2012). Mango fruit peel and 6012 Afr. J. Biotechnol. flesh extracts affect adipogenesis in 3T3-L1 cells. Food Funct. 3:828-836.

\section{How to cite this article:}

Gurumeenakshi, G., N. Varadharaju and Rajeswari, R. 2019. Quality Analysis of Mango Fruit Waste for Utilization in Food Products. Int.J.Curr.Microbiol.App.Sci. 8(03): 20-27. doi: https://doi.org/10.20546/ijcmas.2019.803.004 